\title{
Is a stock overfished if it is depleted by overfishing? A response to the rebuttal of Agnew et al. to Froese and Proelss "Evaluation and legal assessment of certified seafood"
}

Rainer Froese, Helmholtz Centre for Ocean Research (GEOMAR), Marine Ecology, Düsternbrooker Weg 20, 24105 Kiel, Germany, rfroese@geomar.de

Alexander Proelss, University of Trier, 54268 Trier, Germany

\begin{abstract}
This contribution is a response to the rebuttal of Agnew et al. (2012) to Froese and Proelss (2012) "Evaluation and legal assessment of certified seafood". It corrects some factually wrong statements in the rebuttal, revisits the definitions of 'depleted' and 'overfished', and notes that the rebuttal agrees with the international definition of 'overfishing' $\left(F>F_{M S Y}\right)$ that was used by Froese and Proelss (2012). The rebuttal presents an analysis of 45 MSC-certified stocks. Of these, $27 \%$ are 'depleted' (according to the definition used by MSC) or 'overfished' (according to the definition used by Froese and Proelss 2012) and 16\% are subject to 'overfishing', basically confirming the critique of Froese and Proelss (2012). This response concludes that MSC has to change its rules for certification such that (1) overfishing is not allowed and (2) depleted stocks are marked as such.
\end{abstract}

\section{Keywords}

certified seafood; overfished; depleted; overfishing; maximum sustainable yield; eco-labeling

\section{Introduction}

In a recent paper, Froese and Proelss [1] analyzed two binding international agreements, the United Nations Convention on the Law of the Sea [2] and the United Nations Fish Stock Agreement [3], and proposed definitions for the terms 'overfishing' and 'overfished'. They then evaluated seafood stocks certified by Friend of the Sea or the Marine Stewardship Council (MSC) against these definitions. Friend of the Sea has subsequently welcomed the study, has accepted the definitions which were compatible with their own criteria for certification, and has decertified three stocks that were found to be overfished and subject to overfishing. In contrast, staff and advisers of MSC have written a rebuttal [4] to Froese and Proelss [1] wherein they reject the definition of 'overfished' and criticize the methods used for evaluating stocks. Here a response to this rebuttal is provided.

\section{Correction of factually wrong statements}

2.1 The rebuttal claims that Froese and Proelss [1] used an incorrect definition of 'overfished'. As is detailed below, there is no legally binding, or correct definition of that term. Therefore the new definition by Froese and Proelss [1] cannot be classified as incorrect.

2.2 The rebuttal [4] claims that the definition of 'overfished' in Froese and Proelss [1] is at odds with "their own definition specified in a previous publication" [5]. This is factually wrong. Froese et al. [5] say explicitly that they followed the FAO [6] definition of 'overfished' only for comparison purposes 
and stress that FAO's definition of 'fully exploited', "[...] includes stocks that are size- or growthoverfished, where an increase in size at first capture (Beverton and Holt, 1957) or an increase in biomass (Schaefer, 1954) would lead to higher long-term yields".[7,8]

2.3 The rebuttal [4] claims that Froese and Proelss [1] use $B<0.9 B_{M S Y}$ as definition of 'overfished'. This is factually wrong. The definition in Froese and Proelss [1] is: "A stock is overfished if fishing has reduced the stock to a size below the level that can produce the maximum sustainable yield.

Technically, overfished means that the stock biomass $B$ is below $B_{M S Y}$." To account for uncertainty in the estimation of $B$ and $B_{M S Y}$, Froese and Proelss [1] used a range of $0.9-1.1$ to assign stocks as being around the reference point rather than declaring $0.99 B_{M S Y}$ as below and $1.01 B_{M S Y}$ as above the reference point. These practical considerations do not change their definition.

2.4 The rebuttal [4] claims that "[...]in their analysis, Froese and Proelss provide specific estimates of $B / B_{M S Y}$ using their own methodology [...] for 20 out of the 71 stocks they examine [...]. [T]he authors speculate on the status of more than half (51\%) of their analyzed stocks."

These statements are factually wrong. Froese and Proelss [1] made a spreadsheet with all their assessments and sources available together with their study, downloadable from http://www.fishbase.de/rfroese/MSC FOS.xls. This spreadsheet contains not 20 but 35 numerical estimates of $B / B_{M S Y}$ and 38 estimates of $F / F_{M S Y}$. As can be verified in the spreadsheet, precedence was given to original stock assessments. For example, if ICES provided an estimate of $F_{M S Y}$, then that was used. Reference points from Froese and Proelss (2010) [9] were used only if no other estimates were available. The methods used by Froese and Proelss (2010) [9] were not "their own", but consisted, as one of three methods applied in parallel, of a surplus production model [8] such as also used in the rebuttal [4]. If no numerical assessments could be found, then qualitative assessments from original stock assessments were used. If such information was not found, a 'no info' classification was assigned.

\section{Definition of 'overfished'}

The rebuttal [4] claims that the definition of 'overfished' used by Froese and Proelss [1] is not consistent with internationally accepted definitions and interpretations. It provides a table with selected national and international definitions of the term 'overfished' which differ from that submitted by Froese and Proelss [1].

Initially, it should be noted that Froese and Proelss [1] expressly refer to the fact that the definition of 'overfished' used in their assessment differs from that adopted by the FAO, and that "[o]ne of the central problems in international fisheries management is the absence of sufficiently clear definitions of the relevant parameters, or their uniform application, respectively."

The rebuttal [4], by invoking "internationally accepted definitions and interpretations", intentionally or unintentionally creates the impression that the FAO definition was in any way binding upon the MSC. This conclusion does not withstand closer analysis. As was stated by Froese and Proelss [1], no general legally binding and as such recognized definition of the term 'overfished' exists on the international plane. While it is true that the $\mathrm{FAO}$ and also some regional fisheries-management organizations use $0.5 B_{\text {MSY }}$ as a limit reference point, this does not automatically mean that only stocks with a biomass below that point can be considered as overfished. The FAO's Guidelines for the Ecolabelling of Fish and Fishery Products [6], which essentially state that the stock under 
consideration is not overfished if it is above the associated limit reference point (or its proxy), with that limit reference point or proxy being $40-50 \% B_{M S Y}$, are not a legally binding document. The only thinkable way how that definition could have entered into the body of binding international rules and principles is through the development of a corresponding norm of customary international law. However, given that there are only very few definitions of the term 'overfished' available in domestic and international law, it seems impossible to conclude that the necessary State practice and opinio iuris have already evolved. The authors are not aware of a single source claiming that reliance on a limit reference point or proxy of $40-50 \% B_{M S Y}$ for deciding whether a stock is overfished or not is mandatory under customary international law.

It is not without relevance that the EU Commission stated in its Green Paper on the Reform of the Common Fisheries Policy [10] that " $88 \%$ of Community stocks are being fished beyond MSY", meaning that "these fish populations could increase and generate more economic output if they were left for only a few years under less fishing pressure", and treated these stocks as being overfished. Contrary to what is implicitly suggested in the rebuttal, the Commission thus followed the approach taken by Froese and Proelss [1]. Bearing the suggested consequences in mind, it does not seem to make sense to treat only stocks that have fallen beyond the limit biomass as overfished.

The fact that no internationally agreed definition of 'overfished' exists explains why other fishing parameters are of central importance for assessing when MSC should act on the assumption that a stock is overfished. The most relevant of these parameters is that fish stocks have to be maintained at or rebuilt to a size that can support the maximum sustainable yield (MSY). This requirement is, indeed, legally binding under international law [2,3]. Froese and Proelss [1] clarified that while coastal states enjoy a certain scope of discretion in fulfilling the obligation to maintain or restore populations of harvested species at $M S Y$-producing levels, this discretion is not unlimited, since low biomass and low catches have negative impacts with regard to environmental, economic, social and political goals on the long term. They further submitted that the link established by Annex II of the UNFSA between $B_{M S Y}$ and the status of a stock as being overfished cannot be held to be without any relevance. Thus, if available data proves that a certified stock is constantly managed below $B_{M S Y}$, with no chance of reaching that level if excessive fishing pressure continues, this contradicts the binding commitments contained in the UNCLOS [2] and UNFSA [3]. The particular relevance of long-term considerations can also be drawn from the recent communication of the EU Commission [11], which in article 5 defines "maximum sustainable yield" as "the maximum catch that may be taken from a fish stock indefinitely" (EU 2011, Art. 5). It is then a rather formalistic - and, more importantly, equally wrong - line of argument to state that certification was "consistent with internationally accepted definitions and interpretations" since MSC used a definition of "overfished" that in the particular case does not sufficiently pay attention to the obligation to rebuilt fish stocks to a size that can support the MSY. Indeed, an eco-label that does not go beyond the smallest common denominator for fisheries management that the member states of the FAO were willing to politically agree upon ultimately seems to put its own mission into question. North Sea Saithe (Pollachius virens) may serve as an example: as detailed below, management has set the biomass limit reference point for this stock to about $0.2 B_{m s y}$, meaning that, according to FAO and MSC, this stock may be called overfished only if fishing has reduced stock size below $10 \%$ of its unexploited level.

\section{Depleted versus overfished versus recruitment overfished}

The rebuttal [4] states that " $[\mathrm{w}]$ hen stocks are below $B_{M S Y}$ but above their respective limit reference points, they are considered to need 'rebuilding' and are regarded by MSC as 'depleted' (not 
'overfished')". According to an online dictionary, 'depleted' means "weakened severely by removal of something essential". FAO [12] explicitly defines 'depleted' as "[c]atches are well below historical levels, irrespective of the amount of fishing effort exerted" and ranks it as a stock status between overexploited and collapsed. Thus, it seems that, according to this FAO definition, 'depleted' refers to stock sizes below the biomass limit reference point. The FAO Guidelines for Ecolabelling [6], on page 8 , state: "The management system should specify limits or directions in key performance indicators, consistent with avoiding recruitment overfishing..." This suggests that FAO considers stock sizes below the biomass limit reference point as "recruitment overfished", i.e., the same definition as used by Froese and Proelss [1].

In summary, usage of the terms 'overfished', 'recruitment overfished' and 'depleted' is less consistent than suggested by the rebuttal, and thus the proposal by Froese and Proelss [1] of definitions that are compatible with binding international agreements, common sense, and vernacular English seems justified in hindsight. In any case, the analysis of Froese and Proelss [1] shows that $31 \%$ of MSC certified stocks had current biomass estimates that were below the level that can produce the maximum sustainable yield, including stocks that were overfished, depleted, or recruitment overfished.

\section{MSC allows overfishing}

The rebuttal [4] concedes that "... international definitions of overfishing are generally consistent with the definitions used by Froese \& Proelss..." and that "... the MSC standard does not require in all cases for stocks targeted by MSC fisheries to be fished at $F<F_{M S Y}[\ldots]$. There are situations when $\left.F\right\rangle$ $F_{M S Y}$ is allowed for stocks harvested by MSC fisheries, but only where there is evidence that under the management plan, stocks will be kept at or above $B_{M S Y}$, or will be able to recover to $B_{M S Y}$ within defined time limits". In other words, fishing above $F_{M S Y}$ is correctly called 'overfishing', and MSC accepts such overfishing at least temporarily. Froese and Proelss [1] documented overfishing in $30 \%$ of the MSC certified stocks. For example, based on the latest stock assessment [13] for North Sea Saithe, overfishing $\left(F>F_{M S Y}\right)$ commenced with certification in 2008 and continued in 2009, even though biomass fell to below $0.5 B_{M S Y}$ in 2012 [4] and recruitment was below average since 2006 [13]. Management systems that are compatible with the Law of the Sea [2], such as in place in USA, New Zealand or Australia, would have halted or drastically reduced fishing at this point. Instead, ICES [13] advised increasing fishing in 2013 by 15\%, although these catches will consist mostly of juveniles: legal landing size is $30-35 \mathrm{~cm}$, depending on the area, whereas the mean length at first maturity is about $50 \mathrm{~cm}$ [14]. Also, the management reference points for this stock are biased towards overfishing: the reference point for sustainable human induced mortality $F_{M S Y}=0.3$ exceeds the rate of natural mortality $M=0.2$ by $50 \%$ (instead of $F_{M S Y}<=M[15,16]$ ) and the limit reference point for biomass is set at about $0.2 B_{M S Y}$ instead of $0.5 B_{M S Y}[4,13]$. Clearly, this is not a well-managed fishery deserving certification.

Note also that fishing at $F_{M S Y}$ when stock size is above $B_{M S Y}$, as explicitly allowed by MSC [4], means that the catch exceeds the maximum sustainable yield. Catches above MSY are, by definition, unsustainable and are certainly not a management option in line with the respective international agreements $[2,3,17]$. Such very high catches exert a strong impact on the ecosystem and create an incentive for overcapacity [18]. 
There is also an overlooked conference paper by Peter Shelton [19] which provides an independent analysis of several MSC-certified fisheries that "...may not in fact be sustainable using commonly accepted MSY-based criteria". That paper also provides a critical review of the MSC certification process.

\section{In its own analysis, MSC finds $27 \%$ of certified stocks 'depleted' and $16 \%$ with ongoing 'overfishing'}

Although Froese and Proelss [1] made their data available to MSC before publication, the rebuttal [4] does not contain a single case demonstrating that a reference point or an indicator used by Froese and Proelss [1] was wrong. Instead, the rebuttal [4] presents its own analysis of 45 out of 71 certified stocks. Their Figure 1 shows 12 of 45 stocks (27\%) as being 'depleted' (sensu MSC [4]) or 'overfished' (sensu Froese and Proelss [1]) with $B$ below $B_{M S Y}$, and 7 stocks (16\%) with ongoing overfishing with $F$ above $F_{M S Y}$, a result that confirms the critique of Froese and Proelss [1].

\section{Conclusion}

The rebuttal [4] confirms the need for definitions of 'overfished' and 'overfishing' such as those provided by Froese and Proelss [1]. It confirms that some MSC-certified stocks are below $B_{M S Y}$ or fished above $F_{M S Y}$, and that the latter process is correctly called 'overfishing', in agreement with all binding international obligations. The rebuttal presents its own analysis of 45 MSC-certified stocks, with $27 \%$ below $B_{M S Y}$ and $16 \%$ above $F_{M S Y}$, which basically confirms the results of Froese and Proelss [1].

Certification of seafood, such as provided by MSC, is needed to help consumers making the right choices [1]. However, consumers are misled if fisheries are certified where overfishing is ongoing. If fisheries are to be certified where the stock size is still too small but overfishing has ended, then products from these rebuilding fisheries have to be marked as such.

\section{References}

[1] Froese R., Proelss A.. Evaluation and legal assessment of certified seafood. Marine Policy 2012; 36:1284-1289, doi:10.1016/j.marpol.2012.03.017

[2] UNCLOS. United Nations Convention on the Law of the Sea. 1833 UNTS 3. 1982. Retrieved from http://www.un.org/Depts/los/convention_agreements/texts/unclos/unclos_e.pdf in April 2011.

[3] UNFSA. Agreement for the implementation of the provisions of the United Nations Convention on the Law of the Sea of 10 December 1982, relating to the conservation and management of straddling fish stocks and highly migratory fish stocks. 2167 UNTS 88, 1995. Retrieved from http://www.un.org/Depts/los/convention agreements/texts/fish stocks agreement/CONF1 64 37.htm in April 2011. 
[4] Agnew DJ, Gutierrez NL, Stern-Pirlot A, Smith ADM, Zimmermann C, Sainsbury K.. Rebuttal to Froese and Proelss "Evaluation and legal assessment of certified seafood". Marine Policy 2012. Submitted.

[5] Froese R, Zeller D, Kleisner K, Pauly D. What catch data can tell us about the status of global fisheries. Marine Biology 2012;159:1283-1292.

[6] FAO. Guidelines for the ecolabelling of fish and fishery products from marine capture fisheries. Revision 1. Rome; Food and Agriculture Organization of the United Nations; 2009. Downloaded on 14.12.2011 from http://www.fao.org/docrep/012/i1119t/i1119t.pdf

[7] Beverton R.J.H., Holt S.J.. On the dynamics of exploited fish populations. In: Fishery investigations, Series II, 19. Her Majesty's Stationery Office, London; 1957.

[8] Schaefer MB. Some aspects of the dynamics of populations important to the management of the commercial marine fisheries. Inter-American Tropical Tuna Commission Bulletin 1954;1:2556.

[9] Froese R, Proelss A. Rebuilding fish stocks no later than 2015: will Europe meet the deadline? Fish and Fisheries 2010;11:194-202.

[10] EU. Green Paper of the European Commission on the Reform of the Common Fisheries Policy, $\operatorname{COM}(2009) 163$ final; 2009.

[11] EU. Proposal of the European Commission for a Regulation of the European Parliament and of the Council on the Common Fisheries Policy, COM(2011) 425 final; 2011.

[12] FAO. Review of the state of world marine fishery resources. FAO Fisheries Technical Paper. No. 457. Rome, FAO; 2005. Accessed in May 2012 at http://www.fao.org/newsroom/common/ecg/1000505/en/stocks.pdf

[13] ICES 2012a. Saithe in subarea IV (North Sea), division Illa (Skagerrak), and subarea VI (West of Scotland and Rockall). Accessed in July 2012 at http://www.ices.dk/committe/acom/comwork/report/2012/2012/sai-3a46.pdf

[14] ICES 2012b. ICES FishMap, Saithe, Pollachius virens. Accessed in July 2012 at http://www.ices.dk/marineworld/fishmap/ices/pdf/saithe.pdf

[15] Walters CJ, Martell SJD. Fisheries ecology and management. Princeton University Press, Princeton, UK; 2004.

[16] Pikitch E, Boersma PD, Boyd IL, et al. Little fish, big impact: managing a crucial link in ocean food webs. Lenfest Ocean Program, Washington, D.C.; 2012.

[17] FAO. Code of Conduct for Responsible Fisheries. 1995. Retrieved on 14.12.2011 from http://www.fao.org/docrep/005/v9878e/v9878e00.HTM.

[18] Froese R, Branch TA, Proelss A, Quaas M, Sainsbury K, Zimmermann C. Generic harvest control rules for European fisheries. Fish and Fisheries 2011;12:340-351. 
[19] Shelton, P. Eco-certification of unsustainable fisheries. ICES CM 2010/D:07, 17 p. Retrieved from https://sites.google.com/site/sheltonpa/ in May 2012. 